Александра Пауновић

Институт за књижевност

ale.paunovic@gmail.com

821.163.41-1.09 Марковић M.
https://doi.org/10.18485/ai_pesnikinje.2018.ch12

\title{
ИНТИМНЕ (И ДРУГЕ) ИСТОРИЈЕ У ЛИРИЦИ МИЛЕНЕ МАРКОВИЋ
}

У песничком опусу Милене Марковић (1974) питање историје позиционирано је унутар интимног света као утварна сенка далеког, (тешкопевљивог) садржаја. Певање о личном, интиимном: љубави, пореклу, болу одвија се, показаће се, на линији проблематизације зајеgнишитвв. У огледу се издвајају конститутивни и верижни

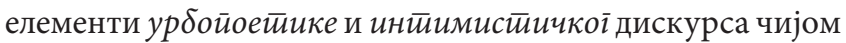
динамиком настаје аутсајдерски свет друштвене маргине са уломцима историјске стихије, али и мрежа лирске самосвести, обележена меланхолично-иронијском осећајношћу, веристичком оптиком, друштвеном критиком и гротеском.

Кључне речи: наративна лирика, урбопоетика, интима, историја, гротеска, иронија, други као љубав, сусрет.

Милена Марковић (1974), како запажа Радмила Лазић, „једна је од ретких аутентичних ауторских личности која је својом појавом и креативношћу током само једне деценије стекла готово неподељене симпатије и велика признања" (2009: 264). Њене збирке песама у издању ЛОМ-а Пас који је йојо сунце (2001), Истиина има тиератье (2003), Црна кашика (2007), Птиччје око на 


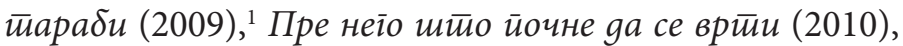
Песме за живе и мрйве $(2014)^{2}$ нису заостале за високовреднованим драмским стваралаштом. ${ }^{3}$ Синергију песничког израза и драматуршког поступка Милена Марковић види као последицу сопственог опредељења и йоетиске жице $e^{4}$ која је у темељу њеног стварања. Споменута песникиња Радмила Лазић, састављајући антологију српске урбане поезије Звезgе су лейе, али немам каg ga их ілеgам (2009), ${ }^{5}$ уврштава десет песама М.

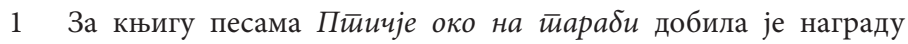
„Биљана Јовановић“ и „Бура Јакшић“ 2010. године.

2 До сада су штампана два издања сабраних песама, такође у ЛОМ-у: Песме (2012) и Песме за живе и мрйве: сабране иесме (2017).

3 Милена Марковић је добитница следећих признања за драмско стваралаштво: специјална награда у Бечу за најбоље драме са екс-Ју простора, две награде Стеријиног позорја за најбољи текст: Нахоg Симеон (2007) и Броg за луйке (2009), награде за драмско стваралаштво „Борислав Михајловић Михиз“ (2007) и награде „Тодор Манојловић“ поводом драме Броg за луйке. Награду „Милош Црњански“ добија за књигу 3 gраме 2010. (више у Марковић 2015: 79-82).

4 У интервјуу за Време, одговарајући о начину комуницирања драме и поезије у сопственом књижевноуметничком стваралаштву, ауторка наглашава: „Моји дијалози увек имају одређену врсту метрике, а за то мора да се има поетска жица и то нема везе са талентом. Радим сонгове често. Сонгове волим зато што јако волим Брехта. Сонгови су ми страшно узбудљиви. Уместо монолога и коментара окренем ствар сонговима. [...] За драму, мора се водити рачуна да све буде изводљиво, психолошки повезано, и разлика је што је драма просто паметнија и она је више у комбинаторикама, а поезија је по мени значајнија. У суштини, радим и једно и друго на исти начин, осим што ми је поезија дража јер је она у неком вредновању литературе на врхунском мјесту. У том смислу ја се примарно сматрам песником, па онда све остало“(Марковић 2013, истакла А. П.).

5 Радмила Лазић истиче да се њена антологија наслања на Шум Вавилона (прир. Михајло Пантић и Васа Павковић, Нови Сад: Књижевна заједница Новог Сада, 1988), а да се „позиционира 
Интимне (и друге) историје у лирици Милене Марковић211

Марковић. Ауторка у Увоgнику прецизира своју методу антологичарског одабира, дајући му поетичко-естетич-

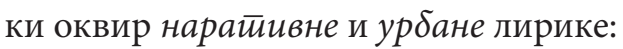

Песници који ће се наћи у овој антологији пишу урбану поезију наративног типа. Када говоримо о урбаној поезији ваља рећи да се ово одређење не односи само на песме које третирају тему града и градског живота, већ овај термин треба схватити много шире - као парадигму модернитета који је у поезију ушао са Бодлером, а представља критику традиционалних вредности и измењен однос према лепоти. Урбаност, дакле, није само ствар амбијената и миљеа, већ представља еманципаторско стање духа, и пре свега ствар је сензибилитета. Урбаност такође подразумева савременост, и одржава дух времена у коме живимо, отвореност за друго и другачије. (Лазић 2009: 19)

Када се погледа поближе низ песама којима је лирско стваралаштво Милене Марковић представље-

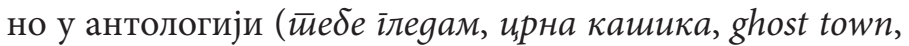
уйробе, курвински яан, моја ћерка, неgељу ӣойоgне, неко је лежао у мом кревейу

између транссимболистичке атологије Речи $u$ сенке и антологије радикалних песничких пракси - Дискурзивна йела йоезије“ (2009: 19). Овако постављена између приређивачког рада Т. Брајовића и Данице Павковић, антологија Радмиле Лазић враћа дуг историје модерног српског песништва према

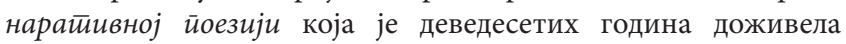
експанзију и била водећи поетички поступак (Лазић 2009: 19).

6 Наслове песама пишемо малим словом, поштујући изворни ірафички ойисак паратекстуалних елемената у поезији Милене Марковић, а према издањима ЛОМ-а (антологија Р. Лазић Звезgе су леиее, али немам каg gа их ілеgам не преноси ову одлику, јер болдираним великим словима уједначава наслове свих песама у антологији). 
оно на тематско-мотивском и језичко-стилском плану поклапа са назначеним књижевнокритичком дескрипцијом и контекстуализацијом Р. Лазић. Наиме, иееме љубавних налажена и мимоилажена карактеристичне су за поезију Ане Ристовић, Владиславе Војновић, Ненада Милошевића и Милене Марковић (Лазић 2009: 24). Надаље, Р. Лазић у сажетом портрету песникиње Милене Марковић, наводи:

Код ње је све саздано на ставу и вери у истинитост чина. Њену креативност пре свега карактерише непоткупљивост и непомодарство, и изоштрена перцептивност на рубне животе и ситуације. Она је бунтовна и осећајна истовремено, зато њену поезију воле исти такви.

Милена Марковић пише из позиције женског лирског субјекта, ослобођеног предрасуда, али затеченог ограничењима стварног живота, у свету разорених вредности и обесхрабрујућих могућности. Њен песнички свет чине односи са блиским особама, али и онај аутентични, маргинализовани свет, који се може срести по ободима града, у социјалном окружењу осујећених и промашених живота [...] Њена поетика је поетика немира и немирења, изражена на онај бунтован, помало дилановски начин, умекшан шелијевском осетљивошћу. (2009: 264, истакла А. П.)

Од прве књиге песама Пас који је йојо сунце (2001) до последње издате Песме за живе и мрйве (2014), Милена Марковић изводи језички експеримент и експеримент форме у антикантовском духу, ${ }^{7}$ градећи йеснике

7 Антикантовски дискурс Павиљона тумачи Светислав Јованов у тексту Уїоgна равнойежа, ойасна очекиваға: „Најзад, прекретнички модус Павиљона почива умногоме и на димезији унутар које пратимо развијенију референцу на 
имаїинайиве тескног, хумористичног, ${ }^{9}$ друштвено-критичког, али не и јасно антиидеолошког (по чему се јасно одваја, на пример, од опуса Биљане Србљановић). При чему, интроспективна унутрашња реалност и сензибилистички хабитус лирског субјекта обликују амбијент и атмосферу са рубних градских простора, тј. границе сопства лирског субјекта и града су неразлучиве. Ойростиоравағе простора града, деридијански казано, ${ }^{10}$ заправо је геомапирање лирског гласа, оиростиораване / изливане садржаја свести и искуства унутар urbis-a. Међутим, Милена Марковић зазире од поделе на „урбано и неурбано“11 и, желећи да се сачува од књижевнотеоријских

Канта, несумњиво повезану са подругљивом парафразом из поднаслова. Као што је метафизичку дилему о идентитету заменило питање о јеловнику, тако се и, на Кантовој филозофији утемељено, повезивање подручја моралног и естетског посредством појма „узвишеног“ овде радикално обрће: атмосфера, мотиви и језик тривијалности и насиља - тзв. „ниског“ - подцртавају жанровски, стилски и језички раскид ауторкине стратегије са условностима идеолошки омеђеног и тумаченог света.“ (2006)

8 Термин је преузет из студије Т. Брајовића Теорија йесничке слике, Београд: Завод за уџбенике и наставна средства, 2000.

9 О хумору у поезији Милене Марковић видети рад Весне Половине у овом зборнику.

10 Реч је о термину из студије Ж. Дериде Позиције (Positions, 1972).

11 Говорећи о својим драмама Вечерне новосиич, Милена Марковић, желећи да се сачува од књижевнотеоријског и књижевнокритичког одређења, наглашава: „Сваки пут када ме ставе у неку фиоку, ја искочим из неке друге. Када сам почела да радим, аутентично сам радила нешто што је био вапај моје генерације. Мене то више не занима. То сам урадила за своје прве две драме: Шине и Павиљони. Прогласили су ме урбаним писцем, иако ми тај термин није јасан. У том смислу спадам у писце проклетнике које се баве на одређен начин људским понорима, и моје теме су биле доста везане за град, али неке и нису. Моја следећа драма Шума блисйа писана са елементи- 
и књижевнокритичких одређења, наводи: „Ја сам, пре свега, песник. Никада не гледам да погодим неки савремени контекст него се бавим поезијом. Мене много

ма мистерије и фантазије дешава се у кафани и ликови никако нису урбани, напротив. Такође и у Нахоg Симеон. Онда су ме ставили у фиоку емоција, а ја само одлучила да напишем нешто очишћено од емоција. Написала сам једну драму са елементима црног хумора и апсурда која се зове Жица. [...] На тај начин размишљам јер сам уметник, а не културтрегер“ (2016). Овакав аутопоетички исказ проистиче из уметникове потребе да себе исказује кроз динамизам креације и форме, а не кроз статичне и стабилизоване књижевнотеоријске појмове и књижевнокритичке приказе. Напоменућемо још, кратко, да зазор од појма $y p \delta a н о \bar{\imath}$

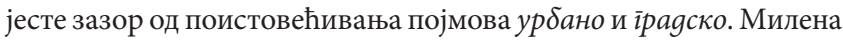
Марковић сликовито коментарише да јој се „диже коса на глави када се ствари деле на урбане и неурбане“. Колоквијално, па

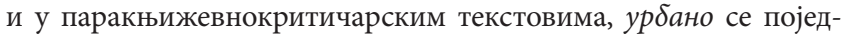
ностављује и једначи са појмовима модерног, прогресивног, са свим оним што су технолошке и културне тековине града. Појам урбано, међутим, опстаје на разини његове разлике према појму града. Ту разлику дефинисао је још Анри Лефевр у есеју Граg и урбано: „Урбано се јасно разликује од града зато што се појављује и манифестује у току распрскавања града, али оно омогућава да размотримо и чак разумемо извесне аспекте који су дуго пролазили незапажено: централност, простор као место сусрета, монументалност итд. Урбано, тј. урбано друштво, не постоји а ипак постоји виртуелно; у друштвеној пракси се појављује неусклађеност пуна смисла, и то преко противречности између хабитата, сагрегација и урбане централности која је битна. Урбано је теоријски појам разлучен и ослобођен процесом какав нам се поставља и каквог анализирамо. То није суштина у традиционалном значењу тог израза како га користе филозофи [...] то је више форма, форма сусрета и окупљања свих елемената друштвеног живота, почевши од плодова земље [...] до симбола и тзв. културних дела. Урбано се манифестује чак у крилу негативног процеса дисперзије, сегрегације, као захтев сусрета, скупљања, обавештења“(Лефевр 1988: 257, истакла А. П.). Ур$\delta a н о$, дакле, шири је појам од традиционалног појма хронотоп града, јер унутар себе чува динамизам места и времена, трансгресивност друштвених форми и облика. 
Интимне (и друге) историје у лирици Милене Марковић215

више занима експериментисање формом“ (2016). Будно око гинокритике запажа, засигурно, идентификацију са функцијом песника (а не песникиње). Овакву стратегију самоартикулисања женских аутора, Дубравка Ђурић у

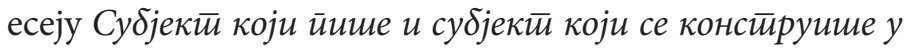
срйској женској йоезији након 1970. іодине класификује у „универзалистичке (стратегије) које заговарају да чин писања није ородњен“ (2016), те се намеће питање односа autopoiesis-a и итендирајућих структура женског

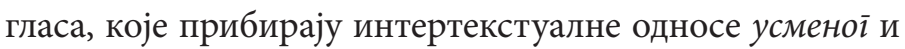
йисаноі̄ у српској књижевности, о чему ћемо касније.

Питање које овде ваља отворити, међутим, јесте

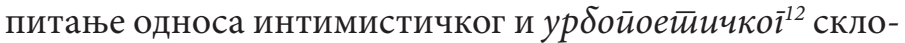
па њене лирике - питање њихових конститутивних и

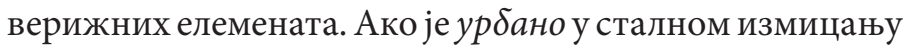
услед своје виртуалне, имагинарне природе - место кога нема, ко су становници урбаних простора? Можемо ли се надати йесничком сииановату, најзад, у динамичном

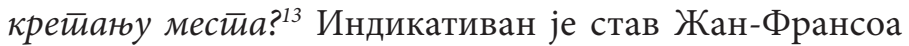
Лиотара из есеја Дом и Меїалойолис, где пориче могућност човековог ygомљеюь, јер данашњи је domus само

12 Урбойоей $и к а$, термин преузет из есеја А. Јеркова посвећен песничкој књизи Граg йopeg светиа (1994) Немање Митровића, означава доминацију урбаног дискурса. Овим књижевнотеоријским појмом А. Јерков се користи како би издвојио доминантне особености пост-урбане прозе „у којој је урбана свест овладала светом, а урбопоетика постала основни израз књижевне имагинације. Читава цивилизација, све културне форме уткане су у ту екуменску фантазију свеграда“" (1994: III, истакла А. П.). Дакле, урбано, свеїраg, меїалойолис има снагу да синтетише цивилизацијске тековине и позицију (пост)модернистичке субјективности. О урбойоетичии у поезији видети Пауновић 2017, о меїалойолису и опусу М. Црњанског Владушић 2011.

13 Термин преузет из студије Динамика ирростиора, крейаюе местиа: сйиgије из іеокулитуралне имаїолоїије (видети Фараго 2007). 
мит, носталгија за нечим што је само предмет илузије. Domus као такав је неодржив, jep megalopolis мења његове традиционалне вредности. Међутим, није реч само о пукој промени, вели Лиотар, него су вредности domus- $a$ преиначене у фасаде, тј. у оно што изгледа као domus, оно је у њега и прерушено и потиснуто насиље (Лиотар, нав. према Leach 2008: 392). Настанити се значи заћи дубље у аветињску мрежу, иза које нас попут тарантуле чекају заблуде о сопственим собама и нама самима. Парадигматичан пример поетизације нелагоде у простору дома јесте песма уйробе из збирке Истиина има йеране. У њој је оиростиораване „места где сам одрасла“ дато у штимунгу језовитог, отуђеног, који је комплементаран упризорењу психопатолошког стања фобије. Међутим, именица gом је у минус-присуству, оно чувено башларовско матиеринсииво куће распршено је у доживљеном ставу лирског субјекта који фиксира и обликује атмосферу предметног света, света без егзодуса, који се лајтмотивски протеже поезијом М. Марковић (сағьам gа моїу gа оййуйујем, ми смо у кући, и оиеети бих, мали, оgо, ирна кашика и др.):

\author{
кад одем тамо где сам одрасла \\ уплашим се \\ да ће нешто да се деси \\ и остаћу тамо заувек у оном мрачном стану \\ са сликама по зидовима \\ и оним завесама \\ невероватно бледе \\ прљавозелене боје \\ изађем увече напоље \\ видим клинце са натученим капама \\ како иду на шему \\ видим девојчице испред улаза
}


Интимне (и друге) историје у лирици Милене Марковић217

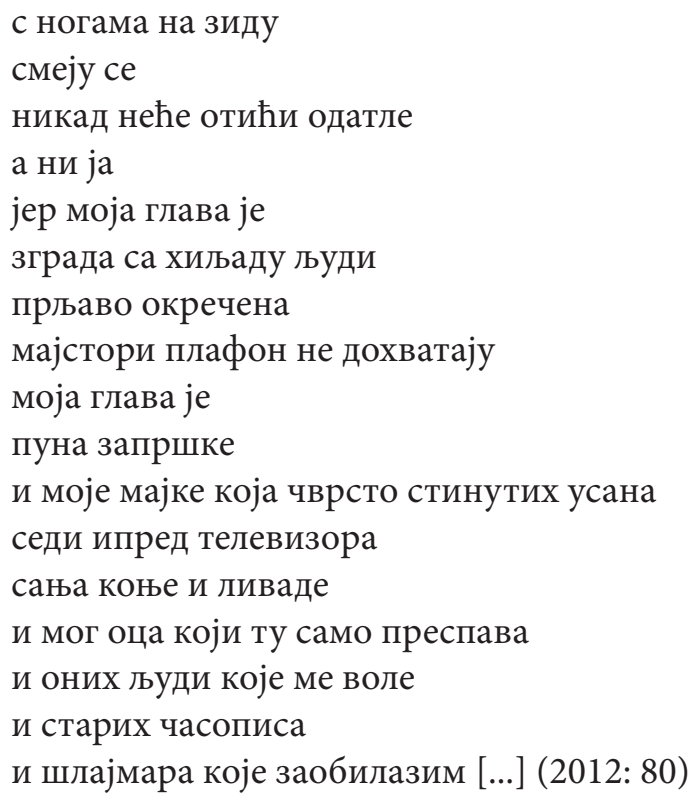

Ритмичко-мелодијски и семантички склоп стихова подражава ток свести, где се интроспекција пресеца са веристичким и друштвено-критичким моментима, при чему је субјективно генеративна снага која асоцијаииивно, у шаламуновском маниру, окупља елементе песминог простора. Ти елементи, обликовани у енциклопедијској ниски / панорамском приказу интимних крајолика битно су обележени одсуством соларног и доминацијом $\bar{u} р љ а в о \bar{\imath}$, које појачава метафора, у маниру В. Попе, утемељена на фразеологизму („у свакој чорби запршка/мирођија“). Надаље, имагинативи ушироба се, у интрспективном такту, ређају поретком п(р)обуђеног страха:

и мандова који продају лубенице

испред зграде 


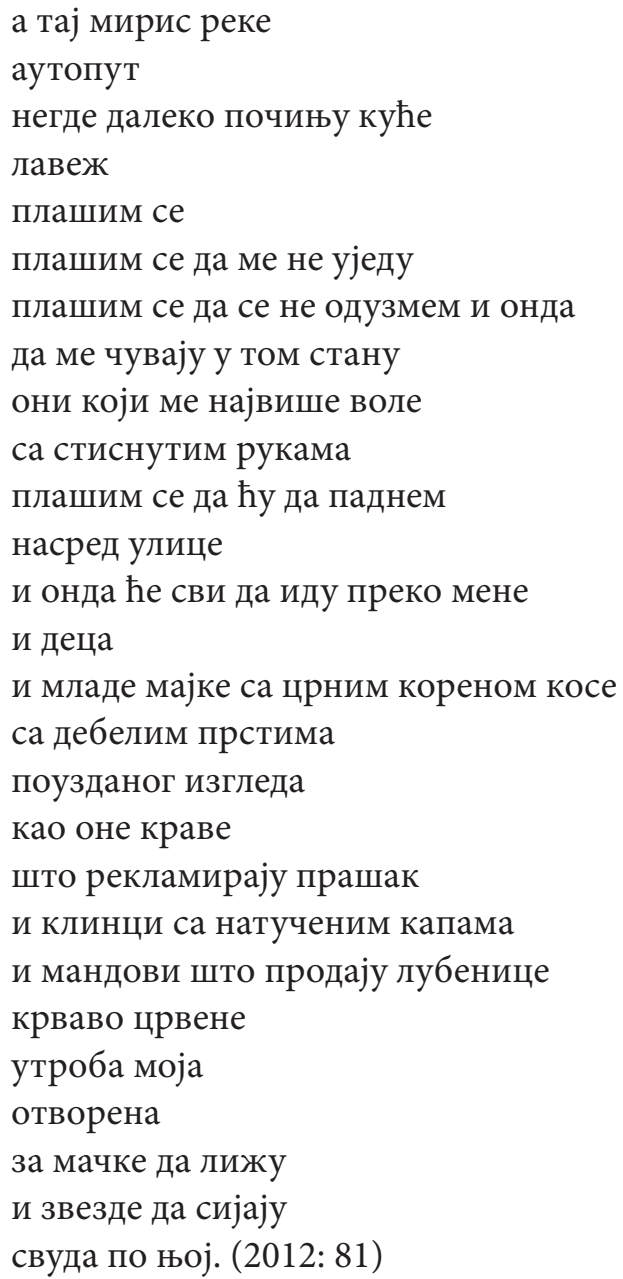

Овај обрт интониран бруталним лиризмом, након краја цикличног асоцијативног низа (фигуре дечака, девојчица и мандова заокружују лирски призор сйољашњеㅎ), двоструке је природе. Наиме, он хелиотропне елементе, који изостају у простору куће одрастања веже за раскомадану утробу и иронијски отвара, 
до тада, херметичан простор света песме. Још једино оно (физиолошко) унуйарюе место није означено / испуњено „запршком“ 14 система, друштвених и класних структура, васпитања и као такво слободно је за звезgани сјај и мачке. ${ }^{15}$ Поовска бића - мачке и контра-небо „раскомадана утроба“ дарују слободу, али једино на начин самоукидања, и таква „уграбљена“ слобода, која се постварује на територији смрти, стално је место у опусу ауторке. Изразито редак епифанијски моменат у песничком језику М. Марковић, стилски брижљиво вајан, дубоко је субверзиван, јер песничка слика отворене женске утробе у феминистичкој визури ${ }^{16}$ јесте

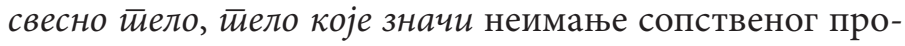
стора. Такво тело, дакле, поставља се у дискурс поли-

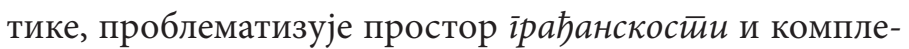

14 У стиховима М. Марковић не запоседају само изван-садржаји просторе личносног већ је искуство субјективитета срасло са процесима стварања унутарњих механизама изопштавања, затварање изнад простора сусрета. Индикативна је, у том

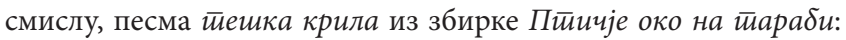
„магла пала на рекламе / птице плове па се спусте на мој кров / па причају / ударају крилима / кад би ушли у те птице / кад би ушле / када би ушла та магла / када би ушла / би ли ме магла поклопила / и птица очи попила / или би се птица заврзла / а магла расточила / од мојих птица из ушију / из моје магле из устију“ (2012: 190). Мотив птица у збирци Птиччје око на

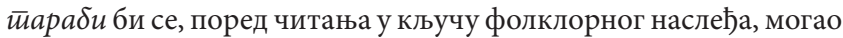
и интермедијално сагледати: кроз поређење, на пример, са филмом А. Хичкога Птиице, али и кроз ликовно стваралаштво Владимира Величковића.

15 Занимљиво да се лексеме „звезде“ и „мачке“налазе у насловима обе антологије које урећује Радмила Лазић: Звезgе су лейе, али немам каg gа их ілеgам (2009) и Мачке не ияу у рај (2000).

16 О читању Милене Марковић из угла феминистичке и постфеминистичке критике видети рад Вере Копицл „Метајезик ишчашеног жанра: постдрамски текст“ М. Марковић у Кюиженсйво, бр. VI (no date). 
ментарност обичаја и закона, наслеђа и искуственог и тражи, рекао би Жак Рансијер, уgео оних којих немају ygeла. На који начин бивамо заједно, ако претпоставимо могућност да оно за пред јеgним буде некорумпирано, конституисано у доброј вољи заједништва? Мухарем Баздуљ, говорећи о споменутој песми и слици породице у њој, примећује родољубиву нит:

Та слика микросвијета породице, рода, толико прецизна и тачна, родољубива је, не само етимолошки, нарочито у кључним стиховима: йлашим се gа се не одузмем и онgа / gа ме чувају у мом сииану / они који ме највище воле. Овај страх и нелагода од тога да чувају они који те највише воле увијек ме подсети на оне прелијепе стихове Душка Трифуновића: Јер моја gуша јасно иоома / gа је најиене међу својима. (2015: 75)

Осцилирајући између иронијских, гротескних и (горко)хумористичних вредности лирски обојена нарација ${ }^{17}$ / наративизација лирског говора М. Марковић

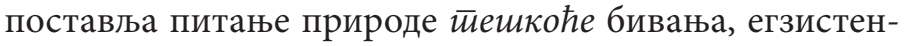
цијалне тескобе у заједници. Песма о, Боже, рано иролеће отвара прву збирку Пас који је йојо сунце. У овој антиидиличној песми, где је топос пролећа девитализован, ${ }^{18}$ а инстанца лирског субјекта деперсонализована - лишена сваког патоса и учешћа на начин присности, амбијент градског простора попут осушене љуштуре

17 По овој топлој лирској црти песништво М. Марковић блиско је песничком опусу Милоша Комадине, који отвара антологију Звезgе су леиее, али немам каg gа их ілеgам (видети Лазић 2009: 28-29).

18 Песма Милене Марковић о, Боже, рано йролеће наставља се на традицију жанровског пародирања традицијских форми и сииалних местиа у српској књижевности, те би се, у том смислу, могла тумачити у поетичко-естетичком одјеку Пролећне иguле В. Петковића Диса. 
Интимне (и друге) историје у лирици Милене Марковић221

обавија приказане догађаје којима су покидане узрочно-последичне везе, затајена йочейности:

\author{
гадан ветар и јако сунце \\ веш на терасама \\ опрана кола \\ која су ударила човека \\ лежи са чудном изврнутом ногом \\ такси чека \\ смушеног да доведе дебелу \\ која тек што је пресекла вене \\ неког малог су тукли \\ онда је притрчао један још мањи \\ и пљунуо га. (2012: 9)
}

У бизарној и гротескној близини оираних кола и човека са чуgно изврнуйом ноіом лирско ја изручује виguк на град и у (за)датој инфлацији говора-објашњења / говора-коментара, под маском persona muta, оставља траг йразнине, с оне стране наративног и дескриптивног. Нарайивизација лирског говора Милене Марковић на микроплану песме динамизује песничке слике изнутра, дајући им хронолошки след, али у ширем, поетичком и естетичком смислу, докида могућност успостављања универзалноі, трансформишући униформисаност језичких знакова и кодова у правцу појединачних значења (зависних од контекста). ${ }^{19}$ У песми Вечносй сликама из породичне историје обликована је

19 Тихомир Брајовић говори о упосебљујућем разумевању, описујући нарацију у поезији као битно поетичко-естетичко средство којим се нивелише „универзалност језичких знакова и њихових реторски устаљених конфигурација“ и постиже „сингуларност њихове вербалноконтекстуалне употребе“ (2005: 18, курзив Т. Б.). 
представа претрајавања у предаји и наслеђивању лор$\delta е р а$ (ловоровог дрвета):

[...] тај лорбер је донео мој брат од ујака

то дрво ће да живи дуже од свих нас

а ја молим молим

да наставе да узимају тај лорбер

они који су остали после нас (2012: 308)

Потребу за универзалистичким значењима као „прежитком“ из потонулог света великих нарација и лоїоценйричним мислима поезија М. Марковић разграђује и на стилистичком плану. Њена слободна рукописна интерпретација правописа условљава минималну употребу интерпункцијских знакова, те су читаве песме најчешће испеване као једна реченица или остављене без обележавања краја. Једнореченична / једноисказна структура преобликовала је и однос паратекста и основног текста песме. Наиме, наслов је врло често неоделит од почетка тирскоі̄ казиваюа, тј. он сам већ значи почетак лирске нарације (анђео са gлакавим йоирсјем, неgељу йойоgне, ирравим кониеитй млаgа, само йи вози, чучим и ілеgам и др.). Оваквим поступцима текстовност песме М. Марковић отвара се у лику илузионисииччкої брзойиса. Њен песнички говор нема времена за подужа увођења, у њему је мера исиисаної једнака мери изіоворльивоі овgе и саga, која је често архаично ритмизована тактовима народних брзалица, разбрајалица, басми ( $\bar{u} и ч ј е ~ о к о ~ н а ~ \overline{и а р а б и) ~ и л и ~}$ је пак заоденут маском брзопријемчивих, популарних песама (сииаклена ӣрашина, мој іолубе, рођени). Матрице масовне културе, оно што је зашло у препознатљив садржај ширем аудиторијуму, у поезији М. Марковић се одваја од окошйалог̄ значења техникама пастижа, 
Интимне (и друге) историје у лирици Милене Марковић223

колажа, гротескном разградњом/надоградњом. Лепљиви садржаји лаког „ужитка" ${ }^{\text {“20 }}$ као идеологеми масовне културе која „обавља улогу утешитеља и умиритеља: [...] чини сувишним трагање за исцрпљеним и личнијим објашњењем пошто даје готов експланаторни модел који убеђује, звучи логично и блиста легитимитетом“ (Анг 2008: 322) одвајају се од својих стабилизованих значењско-обличких схема. У размаку од себе самог, такав садржај од плошне структуре постаје естетизовано концептуално поље кроз које продире садржај йесничке мисли:

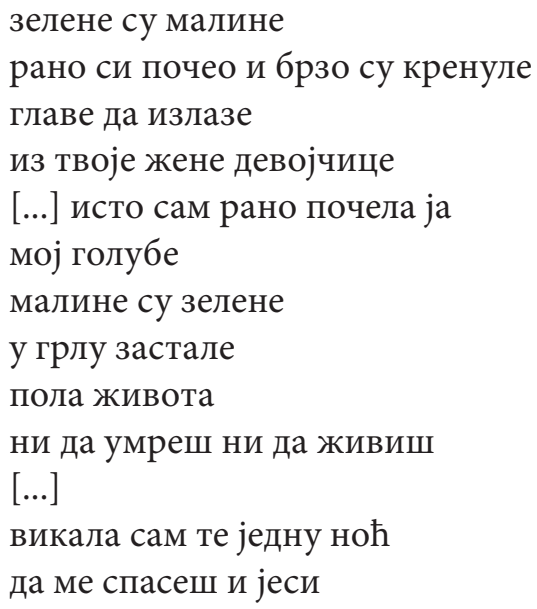

20 „Оно што је застрашујуће у вези са популарном културом нису, како се често тврди, њена наводно механичка или пасивна својства, већ пре, као што Модлеска наговештава, ужитак с којим се она интегрише у дневну праксу. Готово задовољство „шарених“ магазина и холивудских филмова директно се судара с естетским задовољством које величају поклоници високе уметности - класичне и модерне, подједнако. Очигледно да се то естетско задовољство заснива на префињеном укусу чији је нарочити сензибилитет даје и јемчи образовање које, опет, омогућава новац.“ (Олакиага 2008: 532) 


\begin{abstract}
голубе мој са брда
на брдо сам те звала

викала сам једну ноћ

и спасао си јеси

видела сам те кад си био мали

како гребеш ноктима клупу
\end{abstract}

и како никад не знаш шта треба да се каже

и како те бес једе

и једе

и мој бес си добио

дошао ти је на брдо

и сео ти на главу као вештица

са сукњом без гаћа

и седим испишаним длакама

ја тебе нећу никад да спасем

мој голубе

вечно трају сузе девјачке

и сузе момачке

што су пале на малине

на зелене. (2012: 222-223)

Минималистички приступ у пољу ірабостилема коегзистентан је језичком регистру сленга, жаргона, вулгаризама, али и фолклорним формама, мотивима. ${ }^{21}$ Обликотворни чиниоци песминог простора јесу и садржаји, видели смо, масовне културе (у свим њеним видовима кича и шунда), поп музика, ${ }^{22}$ рокенрол, турбофолк... Песничко мишљьене је урасло и/или израсло

21 О деконструктивистичким стратегијама фолклорног коิда унутар драме Броg за луйке М. Марковић видети ПешиканЉуштановић 2010: 587-601.

22 О мотивима популарне југословенске музике који се преобликују у песништву М. Марковић видети Баздуљ 2015. 
Интимне (и друге) историје у лирици Милене Марковић225

из света, из свих његових профаних култова и симбо-

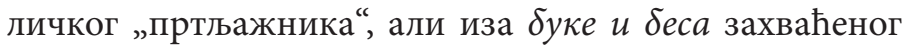
света одвија се једна поезија залеђине. У песми коло читаоци су ухваћени рефренским варирањем стиха „сики нана чоколад банана“, који је, чини се, неподношљиво бесмислен и когломератом комада „од различнијих песама“:

сики нана чоколад банана

и мој живот под кишом

а цури са плафона

и не раде светла

сад

печемо паприке

љути снови прошли дани

мало туђи мало сами

сики нана чоколад банана

ја сам ту

умивам се кишом

истом

и идем на извор

исти

И ти

шта ћеш сад

имаш ли решење

сики нана чоколад банана

када киша

пробушила

кров. (2012: 294)

Одакле је потекло „сики нана чоколад банана“? Како разлучити говор лирског субјекта од његовог оз- 
вученьа у простору (друштвено-историјском, симболичком), где се креће унапред трасираним каналима (све)присутних представа, звукова, флоскула? Лирски субјекат М. Марковић не гаји мит о јединствености и самониклости, његове су границе сопства йорозне, он говори кроз свет смехом. Смех који кружи овом лириком, међутим, дубоко је упитан, вишесмислен. Жан Бодријар је забележио да је смех

најчешће животно реаговање на згађеност коју добијамо од мешовитог стања или од чудовишног промискуитета. Ми повраћамо равнодушност, али нас она у исто време и опчињава. Волимо све да мешамо, али нам је у исто време и мука од тога. То је животна реакција којом организам чува свој симболички интегритет [...] (1994: 70).

Испод детронизације предмета песничког мишљења и естетике йрљавоі и йagнō̄ у гротескним сликама положено је питање, вратимо се сада њему, о немогућности зајеgнишиива. Сетимо се Аристотела и његовог одређења града на које се и Ж. Рансијер позива у књизи Несаїласносй: „У односу на остале животиње управо је људима својствено да имају осећања добра и зла, правде и неправде. Управо је заједница тих ствари ствара породицу и град“ (Аристотел I, 1253 а, цит. према Рансијер: 17).

Шта има од праведности у „један је још мањи / дошао и пљунуо га“, кашици „на коју зову избеглице“ (летио gевеgесетиирве), у корачању одсечном између гробова „и не могу да нађем тај један“ (љубави), знању да аутобус не долази „јер је порушен део града / живи смо здрави смо / мостови затворени“ (бомбарgовағе) или пак у чињеници „знам да би мислили на мене / можда и више него / што ја мислим на вас / зато што би били бољи људи / него што сам ја / да сте на пример / живи. 
Интимне (и друге) историје у лирици Милене Марковић227

(морнари војници)? Ништа. Категорије добра и зла су непрозирне, аксиолошка матица лирског света М. Марковић је предата бујици. Међутим, човек је, просудиће Ж. Рансијер „субјекат односа свега и ничег, збуњујући кратки спој света бића који се рађају и умиру и израза једнакости и слободе“ (2014: 112) и у том збуњујућем кратком споју М. Марковић лирски, продорно, „са осетљивошћу не само за своје ране“ (Лазић 2009: 12), усред нерашчитљивости „законика“ разорених предела Црниіраgа и бића, пева о оном елементарном - о открићу себе йреg изричитим условом gа се буgе вољен:

[...] срамота ме а легла би на траву и певала дођи дођи дођи

шта је живот

дођи

имам ја и ливаду и поток

и дрво што цвета

биће ујутру боље ако

дођеш без да те позовем

него тако

дођи травом

и дрвећем

ноһ je

ћорава. (2012: 285, истакла А. П.)

Наиме, не само да је њена поезија „љубавних налажења и мимоилажења" (Лазић 2009: 12), већ је поезија темељно запитана над смислом оноїа који воли, јер ниједно питање радикалније не дотиче „од питања које ме испитује: „'Постојим ли док мислим?' - осим онога: 'Воли ли ме неко - споља?'“, каже Жан Лик-Марион (2015: 53). Тај неко сйоља, којег лирско ја призива иесмом у великом ишчекивағу јесте gоїађај, ексиеннзија 
gоїђаја којим се (ре)дефинише време, јер темпоралност чекања укида време као екстензију духа (Марион 2015: 46-47). Пев у трави - могућност да се лирски субјект gоїађа самоме себи „као дат и обожаван феномен, који је ослобођен таштине“ (Марион 2015: 34) изручен је простору locus amoenus-a (ливада, поток, расцветано дрво), издвојен је из ћораве ноћи, guвљеі̄ бића постојања. Фигура gpyīōi, онога који долази и својом љубављу обезбеђује еізистиеницјалну извесносй лирском субјекту, дакле, оног који (раз)обручује интимно простором зајеgничкої обликована је ретким мотивима

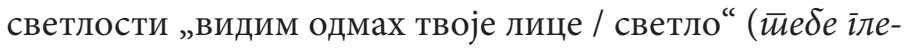
gaм). Једино биће вољеног баца сенку у лирском свету М. Марковић: „отићи ћу до реке мили / са сенком твојом / дугачком“ (мили) и једино је њему придодат анђеоски тик (анђео са ялакавим йоирсјем). Са друге стране, његов изостанак раскриљује демоничност простора и других. У песми млеко, прецизне архитектонике, која је достојна једне тадићевске демонизације градских предела, међутим, време чекања је огољено до болних трагова:

\author{
да те чекам је ли \\ да те чекам да престанеш да чекаш \\ путеви су пуни оних што чекају \\ гробља су пуна оних што чекају \\ ја нећу више да чекам \\ боли ме млеко \\ што ми тече \\ према земљи \\ боле ме уши \\ теме од речи \\ боле ме путеви од слободе \\ боли ме крв на лишћу
}


Интимне (и друге) историје у лирици Милене Марковић229

на жутом

боле ме ноге од туђих ногу

боле ме очи од погледа

нећу да чекам

и нећу да ме гледају

ови што чекају

зато што знам да имају папке

сакрили су испод стола. (2012: 184)

Разбољене очи од погледа јесу разбољене од себе самих - онога што гледају и оних који у њих гледају, јер шта може значити поглед који се утискује жигом боли? Очима исйоg света, испод баре песништво М. Марковић гледа у зглобна места зајеgнишйва, додира инииимноі̄ и gруі̄ōi, која остају празна:

после смо почели да живимо заједно

и унаказили смо једно друго

тада ми је одлетело

оно што се зове душа

сад се некад врати

седи ми ко мајмун на рамену

и каже

онај твој дивни камарад

он има плаве очи

има две хиљаде зарона

разочаран је у не знам ни ја у шта

има очи озбиљног примата

(мајмун на рамену, 2012: 110)

Детронизацијом душе и gивноі камараgа песма се окончава ипак са зайвореним очима, јер не наступа раздобље среће (kairos) због које би умрла насмејана / ойворених очију (2012: 110). У песми $\delta и \bar{u} и$ танатолош- 
ки мотив „изокреће“ позицију наслова. Наиме, морфолошки и семантички, наслов се надовезује на последњи стих, тј. паратекст постаје оно нейоказиво:

[...] шта то мене брига

то пола песме

нећу да ти покажем

јер ту ће да пише

шта ће да буде

други дан

да не дођеш

други дан

да не дођеш

мене неће. (2012: 117)

Смрт вољеног и исписан нестанак субјекта су немогући у међусобној повезаности, субјекат пребива у онтолошкој одвојености од онога што га, у битном смислу, дефинише, али и у болној одвојености у смрти од вољеног. Сопствену егзистенцијалну извесност „једино је неко други поред мене самог може обезбедити“ (Марион 2015: 35), а када тај други нестане - непоказива је песма о томе. Оно непоказиво, gруїо ииело иеесме са пунином садржаја који неповратно изостају са меланхоличном сенком свог присуства попут река йонорница круже лириком Милене Марковић - простором града

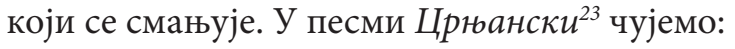

ја сам патила због изобиља

по туђим градовима

по туђим улицама људи

23 Песму је М. Марковић прочитала приликом доделе награде „Милош Црњански“. 
Интимне (и друге) историје у лирици Милене Марковић231

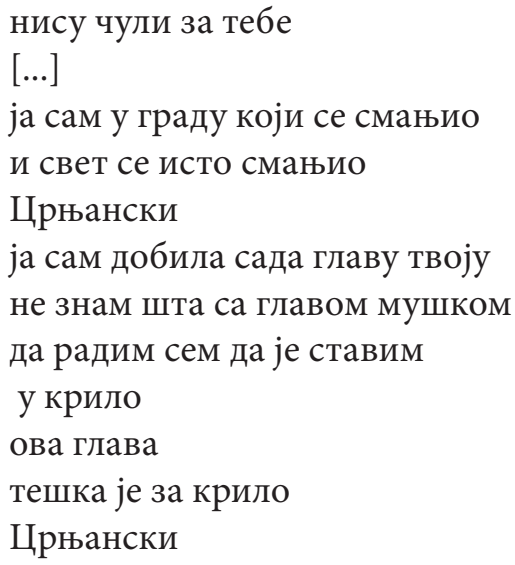

Град и свет се смањио, главу поете не чека ни бело платно, ни жртва покорног слуге, ни царство не-

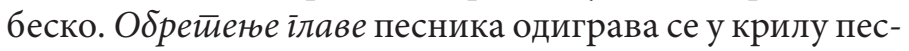
никиње и/или женског гласа песника, што је алегореза ca аутопоетичким имликацијама par exellance. Надаље, питамо се, колико је gека gуше тешка глава Црњанског у йесмама за живе и мрйве? Оно чега нема зри и чека да се у ойаибини сусретне лицем у лице са лирским субјектом у брисаном простору из кога пева:

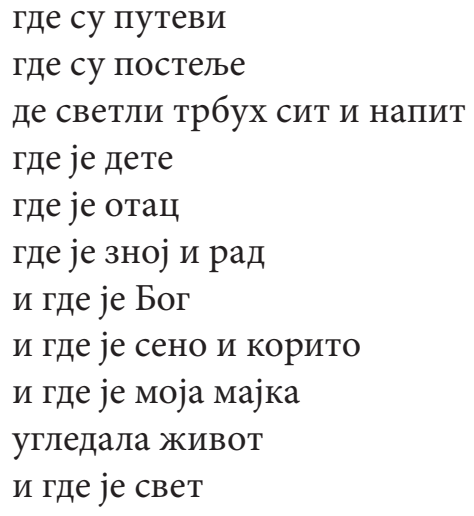


где је душа у мајци мојој

где је отац где је сестра

и небо и хлеб

шта је то

о чему ви причате по тим баштама

шта радите људи

где је душа човека

где је моја душа

да ли је то све

да ли је то све (2015: 64)

Као што је у маленој банској Косово мајчевина тако је ойаибина територија самоделања, где се геопоетичко, али и геополитичко питање Гge сам ја? раствара до питање душе (psychē), до питања īge je gyша моје мајке (мајка-ойаибина рекао би Угљеша Шајтинац).

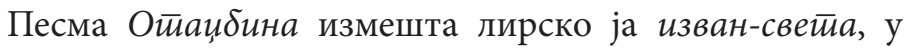
нигдину, непокретност без оgіовора. Она је складиште неимајућих ствари, иррича која су изі̄убиле равнойежу, обесмишљених појмова, растемељених простора завичајности. То је, може се рећи, Сербиа Милоша Црњанског које је остала без ониричке и метафизичке осене суматраизма. Рефренско и завршно ga ли је $\bar{u} о$ све и стииіло ме је све из малене бағске призива пролошке стихове Лирике Ийаке: „Ја видех Троју и видех све“ (Црњански 1966: 13-14). Ђаво нас, међутим, није однео, остаје се „на тој опасној стази /ничим доказане слободе“ (бивии gруї, 2012: 276-277).

Аморфни простор ойаибине у коме никаква аксиолошка оријентација није могућа, тај непознати простор који протеже с ону страну сусретиа и чекаға, некосмизирани по својој природи, дакле, неприпојен човековом бићу, наставља йразнину из искуства субјективитета која се не да̂ видети. Окренемо ли поглед пре- 
Интимне (и друге) историје у лирици Милене Марковић233

ко празнине gома, погледом анђела у лирици Милене Марковић, сусрешћемо бењаминовску олују, једини облик тзв. прогресивног историјског кретања, али и, испод свих наслага културе спектакла, чезнутљиво сопство које тек у сусрету са другим задобија своју затурену ентелехију, јер ипак „постоји нека ноћ када си / доживео чисту срећу“ (2015: 63).

\section{Извори и литература}

Ang, Ien. „Dalas i ideologija masovne kulture“. Studije kulture: zbornik. Jelena Đorđević (prir.). Beograd: Službeni glasnik, 2008. 329-339. Štampano.

Баздуљ, Мухарем. „Помало је такијех песника...“. Малена Банска. Задужбинско друштво „Први српски устанак“, 2015. Штампано.

Bodrijar, Žan. Prozirnost zla: ogled o krajnostima fenomena. Miodrag Radović (prev.). Novi Sad: Svetovi, 1994. Štampano.

Брајовић, Тихомир. „Превладавање реторике у песништву Борислава Радовића“. Изабране йесме Б. Раgовића. Београд: Завод за уџбенике и наставна средства, 2005: 7-25. Штампано.

Vladušić, Slobodan. Crnjanski, Megalopolis. Beograd: Službeni glasnik, 2011. Štampano.

Ђурић, Дубравка. „Субјект који пише и субјект који се конструише у српској женској поезији након 1970. године“. Книженстиво, бр. 6 (2016). Веб: 8. 6. 2018.

Јерков, Александар. „Немања Митровић: Граg йореg свейа“, Борба, 72, 304 (1994): III. Штампано.

Jovanov, Svetislav. „Ugodna ravnoteža, opasna očekivanja.“ Sarajevske sveske. br. 11/12 (2006).Veb. 8. 6. 2018.

Lazić, Radmila. „Uvodnik“. Zvezde su lepe, ali nemam kad da ih gledam. Radmila Lazić (ur.). Beograd: Samizdat B92, 2009. 11-15. Štampano.

Leach, Neil. „Tamna strana Domusa“, Tvrđa, br. 1-2 (2008). Štampano. 
Лефевр, Анри. „Град и урбано“. Социолоіија іраgа: социолошка хрестиоматиија. Београд: Завод за уџбенике и наставна средства, 1988. Штампано.

Marion, Žan Lik. Erotsi fenomen: Šest meditacija. Sanja Milutinović Bojanić, Kristina Bojanović (prev.). Novi Sad: Akademska knjiga. 2015. Štampano.

Marković, Milena. Pesme. Beograd: LOM, 2012. Štampano.

Марковић, Милена. „Цинизам је последње уточиште недаровитих“. Време. (27. јун 2013): Веб. 8. 6. 2018.

Марковић, Милена. Малена Бағска. Аранђеловац: Задужбинско друштво „Први српски устанак“, 2015. Штампано.

Марковић, Милена. „Обручке смо прихватили површност“. Вечернее новостии (2016). Веб. 8. 6. 2018.

Olakiaga, Seleste. „Prolog za Megalopolis“. Studije kulture: zbornik. Jelena Đorđević (prir.). Beograd: Službeni glasnik, 2008. 529 - 538. Štampano.

Пауновић, Александра. На путу ка једном gруіом їраgy Владе Урошевића“. Читиане и молк: читиане на макеgонскайа

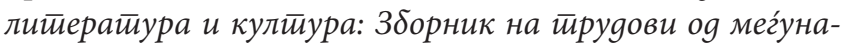
роянатиа научна конференција „Критичка и молк: читиане

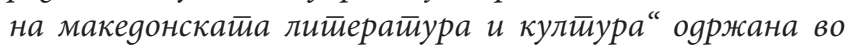
МАНУ на 7 и 8 ноември 2016 іо инна. Скопје: Институт за македонска литература, 2017. 445-457. Штампано.

Пешикан Љуштановић, Љиљана. „Бајка као културни код у 'Броду за лутке' Милене Марковић“. Кюижевносӣ и култиура, бр. 39/2 (2010): 587-601. Штампано.

Ransijer, Žak. Nesaglasnost. Beograd: Fedon. 2014. Štampano.

Farago, Kornelija. Dinamika prostora, kretanje mesta: studije iz geokulturalne imagologije. Novi Sad: Stylos, 2007. Štampano.

Црњански, Милош. Поезија. Београд: Просвета, 1966. 
Интимне (и друге) историје у лирици Милене Марковић235

\title{
Aleksandra Paunović
}

\section{INTIMATE (HI)STORY IN THE LYRIC POETRY OF MILENA MARKOVIĆ}

\begin{abstract}
Summary
In the lyrical works of Milena Marković (1974) the question of history is placed within an intimate world as a ghostly shadow with a distant (unsingable) content. Singing about the motherland and ancestry, about pain and anxiety unfolds in the context of "sumatraistic" poetry, in a place where Miloš Crnjanski resemanticizes the myth about Serbian nation - the great story about the Male. The urban poetry of Milena Marković stems form a specific language which rejects the established norms and uses slang and jargon. On the other hand, these sub-cultural linguistic forms point to the problem of the space of urbanity and the complementarity of laws and customs, of heritage and the empirical. The politics and the position of a woman's writing as simultaneously the subject and object of culture (argument of Rachel Blau DuPlessis) are coupled with the poetic thought about her share in the historical. The poem collections Ptičje oko na tarabi, Pre nego što počne da se vrti, and Pesme za žive i mrtve are characterized by an intimistic discourse, an ironically melancholic sensibility and a veristic approach. In an ideal-philosophical sense, the previously mentioned collections, underneath the auto-creation / textuality of a woman's lyrical voice, express inconsistencies of the social order, the unquantifiable in the redistribution of social bodies and roles. The author of this experiment places the understanding of these questions in the scope of meeting between hermeneutics of literature and modern theories of gender and diversity, the politics of reading and poetry.
\end{abstract}

Key words: memory structures, (post)nation, intimacy, history. 